\title{
Risk Management in the Metal Casting Industry: Case in Ceper Klaten
}

\author{
Sadi $^{1}$, Zuhrohtun ${ }^{2}$, and Indra Kusumawardhani ${ }^{2}$ \\ ${ }^{1}$ Department of Industrial Engineering, Universitas Pembangunan Nasional "Veteran” Yogyakarta \\ ${ }^{2}$ Department of Accounting, Universitas Pembangunan Nasional "Veteran" Yogyakarta \\ e-mail: sadi@upnyk.ac.id
}

\begin{abstract}
This study investigates the implementation of risk management in the metal casting industry. Previous research examines risk management in the production process, while this research identifies risk management in business processes. The research sample is 68 companies incorporated in Batur Jaya cooperatives, Ceper Klaten. This research uses survey method. Business risk management consists of four dimensions: business strategic risk, operational risk, reporting risk and regulatory risk. The results showed that the implementation of business strategic risk, operational risk and reporting risk were good enough. The implementation of regulatory risk management is the lowest compared to the other three risk management dimensions.
\end{abstract}

Keyword-strategic business risk, operational risk, reporting risk, regulation risk, metal casting.

\section{INTRODUCTION}

$\mathrm{S}$ MALL and medium industries engaged in the metal sector are quite numerous in number, but the way of managing these industries in general is still done traditionally with the ability in the field of metal casting and managerial techniques is still very limited [1] conducted research on the identification of risk sources and risk assessment in the metal casting industry of PT. Bonjor Jaya in Ceper Klaten, by making SOPs for workers. In the process of identifying and evaluating the risk of occupational accidents and the risk of occupational diseases in conventional metal casting rooms are: SOP design for workers who carry out the lifting of raw materials from trucks, filling raw materials into the kupola kitchen and the operation process of the kupola kitchen is labor those who are most at risk of occurrence of workplace accidents in the workplace, besides being exposed to chemicals which can interfere with the health of the workforce. The SOP design pattern of the three activities is analyzed based on the existing sources of danger and efforts to control the risk of hazards at work having the risk of workplace accidents in the workplace, but in the SOP the activities of filling raw materials and combustion processes in kupola kitchens are activities that contain hazards. The combustion process in the kitchen provides radiation effects of silicon and manganese particles. In this study, it provides an illustration if SOPs have been determined, it can be known the sources of work hazards so that efforts can be made to control the workplace environment by using personal protective equipment in accordance with the level of work risks that exist and supervise the workplace environment. Thus the
Table 1.

Respondent Characteristic

\begin{tabular}{lrr}
\hline \hline \multicolumn{1}{c}{ Characteristic } & $\mathrm{N}$ & Percentege (\%) \\
\hline Age (years old) & 12 & $17.65 \%$ \\
$20-30$ & 22 & $32.35 \%$ \\
$31-40$ & 34 & $50.00 \%$ \\
$>40$ & & \\
Gender & 51 & $75.00 \%$ \\
Male & 17 & $25.00 \%$ \\
Female & & \\
Occupation & 8 & $11.76 \%$ \\
Owner & 6 & $8.82 \%$ \\
Secretary & 5 & $7.35 \%$ \\
Director & 14 & $20.59 \%$ \\
Manager & 23 & $33.82 \%$ \\
Supervisor & 12 & $17.65 \%$ \\
Staff & & \\
Education & 2 & $2.94 \%$ \\
Junior High School & 29 & $42.65 \%$ \\
Senior High School & 20 & $29.41 \%$ \\
Diploma & 17 & $25.00 \%$ \\
Undergraduate & 0 & $0.00 \%$ \\
Postdraduate &
\end{tabular}

Table 2.

Risk Management Implementation

\begin{tabular}{lcc}
\hline \multicolumn{1}{c}{ Risk Dimension } & $\mathrm{N}$ & Average \\
\hline Strategic Risk & 68 & 3.8 \\
Operational Risk & 68 & 3.8 \\
Reporting Risk & 68 & 3.7 \\
Regulation Risk & 68 & 3.6 \\
\hline \hline
\end{tabular}

draft SOP can be used to resolve the problem of occupational diseases and work accidents so that work safety control efforts can be realized in PT. Bonjor Jaya Klaten.

This research is different from Damanik et al. (2016), namely identifying the implementation of risk management in all business processes in the metal casting industry. The benefits of assessing and implementing risk management are as follows: (a) Increase the likelihood of achieving company goals and improve performance in both financial and nonfinancial performance; (b) Encouraging proactive and anticipative management / management; (c) Provide a sound basis in decision making and planning; (d) Increase the effectiveness of the allocation and efficient use of company resources; (e) Improving compliance with regulations (AMDAL, labor law, PERDA etc.); (f) Increase the 
The $1^{\text {st }}$ International Conference on Business and Engineering Management (IConBEM 2020)

February $1^{\text {st }} 2020$, Institut Teknologi Sepuluh Nopember, Surabaya, Indonesia

Table 3.

Strategic Risk Management Implementation

\begin{tabular}{|c|c|c|}
\hline No & Strategic Risk Implementation & Average \\
\hline 1 & $\begin{array}{l}\text { In the casting industry, the presence of new } \\
\text { entrants (competitors) can threaten the } \\
\text { company's position }\end{array}$ & 3.7 \\
\hline 2 & $\begin{array}{l}\text { Damaging prices in the metal casting industry } \\
\text { can threaten the fulfillment of the company's } \\
\text { top priority }\end{array}$ & 4 \\
\hline 3 & $\begin{array}{l}\text { Unforeseen actions from competitors in the } \\
\text { market place threaten the company's } \\
\text { competitive position. }\end{array}$ & 3.8 \\
\hline 4 & $\begin{array}{l}\text { Unforeseen changes in the market threaten the } \\
\text { company's competitive position. }\end{array}$ & 3.8 \\
\hline 5 & $\begin{array}{l}\text { Major disasters (eg earthquake) threaten the } \\
\text { company's ability to maintain security during } \\
\text { operations, provide important services and / } \\
\text { or recover operating costs. }\end{array}$ & 4 \\
\hline 6 & $\begin{array}{l}\text { Technological shifts and changes in the metal } \\
\text { casting industry can threaten a company's } \\
\text { business }\end{array}$ & 3.5 \\
\hline 7 & $\begin{array}{l}\text { Product or service failures threaten a } \\
\text { company's ability to maintain customer } \\
\text { satisfaction, expand its market or otherwise } \\
\text { negatively impact a company. }\end{array}$ & 3.9 \\
\hline 8 & $\begin{array}{l}\text { The ineffectiveness of the strategy planning } \\
\text { process will result in irrelevance of } \\
\text { information which will threaten the } \\
\text { company's ability to formulate the feasibility } \\
\text { of a business strategy. }\end{array}$ & 4 \\
\hline 9 & $\begin{array}{l}\text { If the company is not effectively led, resulting } \\
\text { in lack of direction, lack of focus on } \\
\text { customers, and decreased motivation of all } \\
\text { company employees. }\end{array}$ & 4.3 \\
\hline 10 & $\begin{array}{l}\text { If the company loses customers, core } \\
\text { employees, or the ability to compete will have } \\
\text { an impact on the company's reputation in the } \\
\text { market. }\end{array}$ & 4.1 \\
\hline 11 & $\begin{array}{l}\text { Business disruptions originate from } \\
\text { technology failures, equipment failures or } \\
\text { events which result in adverse impacts on } \\
\text { operations. }\end{array}$ & 3.7 \\
\hline 12 & $\begin{array}{l}\text { Companies can implement processes or } \\
\text { services quickly enough to offset changes in } \\
\text { the market. }\end{array}$ & 3 \\
\hline
\end{tabular}

confidence of stakeholders; and (g) Increase company resilience through improving product quality.

\section{A. Research Objective}

The objective of this study is to investigates the implementation of risk management in the metal casting industry

\section{B. Risk Management in the Metal Casting Industry}

Vignesh and Dhiravidamani (2015) conducted a risk analysis that occurred in the process High Pressure Die Casting uses Hazard Identification and Risk analysis, besides analyzing all unsafe work procedures and explaining Safe Operating Procedures to workers to be able to carry out their work in a safe manner [2]. Analyzed the new sand casting testing technique based on fault tree analysis, Heinrich Accident Triangle, hazard and operability-layer of protection analysis (HAZOP-LOPA) and components of the bow tie model. The minimum cut sets and minimum path sets are determined based on fault tree analysis then the sand casting explosion accident frequency is calculated based on the Heinrich Accident Triangle. The risk level of ventilation quality can be reduced by using HAZOP-LOPA, the residual
Table 4

Operational Risk Management Implementation

\begin{tabular}{|c|c|c|}
\hline No & Operational Risk Implementation & Average \\
\hline 1 & $\begin{array}{l}\text { Production processes that cannot meet customer } \\
\text { desires can affect future income. }\end{array}$ & 4.3 \\
\hline 2 & $\begin{array}{l}\text { Lack of relevant and reliable information about } \\
\text { existing contract commitments results in } \\
\text { decisions that are not in the best interest of the } \\
\text { company. }\end{array}$ & 4 \\
\hline 3 & $\begin{array}{l}\text { The proper process of allocating company } \\
\text { resources can improve / maintain a company's } \\
\text { competitive advantage. }\end{array}$ & 4.2 \\
\hline 4 & $\begin{array}{l}\text { The company provides physical security and } \\
\text { other aspects of the work environment conducive } \\
\text { to ensuring employee safety and satisfaction on } \\
\text { an ongoing basis. }\end{array}$ & 3.6 \\
\hline 5 & $\begin{array}{l}\text { Lack of training, knowledge, skills, career } \\
\text { opportunities, or experience from key company } \\
\text { personnel threatens the achievement of critical } \\
\text { business goals. }\end{array}$ & 3.9 \\
\hline 6 & $\begin{array}{l}\text { Ineffective lines of authority, failure to set } \\
\text { policies or clear authority limits cause managers } \\
\text { or employees to do things they should not do or } \\
\text { fail to do things that they should. }\end{array}$ & 3.9 \\
\hline 7 & $\begin{array}{l}\text { Subjective measures of performance (reward and } \\
\text { punishment) cause managers and employees to } \\
\text { act in ways that are inconsistent with the goals, } \\
\text { strategies, ethical standards, and business } \\
\text { practices of the company. }\end{array}$ & 2.3 \\
\hline 8 & $\begin{array}{l}\text { Deliberate misstatements from financial } \\
\text { statements or misuse of assets adversely affect } \\
\text { the reputation of the company or cause the } \\
\text { company to suffer financial losses }\end{array}$ & 4.1 \\
\hline 9 & $\begin{array}{l}\text { Fixed assets, financial assets, or company } \\
\text { information are used for legitimate or ethical } \\
\text { purposes by employees / people outside the } \\
\text { company. }\end{array}$ & 3.6 \\
\hline 10 & $\begin{array}{l}\text { The organizational structure of a company has a } \\
\text { positive impact on a company's ability to react to } \\
\text { changes, or a positive impact on a company's } \\
\text { ability to meet its business strategy }\end{array}$ & 3 \\
\hline 11 & $\begin{array}{l}\text { Inefficient and effective operations can threaten } \\
\text { a company's ability to achieve business goals. } \\
\text { Limited supply of raw materials or problems }\end{array}$ & 4 \\
\hline 12 & $\begin{array}{l}\text { with vendors can threaten the company's ability } \\
\text { to provide quality services at competitive prices. } \\
\text { The process of developing metal casting }\end{array}$ & 4.1 \\
\hline 13 & $\begin{array}{l}\text { products is carried out consistently following } \\
\text { consumer demands }\end{array}$ & 4 \\
\hline 14 & $\begin{array}{l}\text { Delivery of products to consumers is always on } \\
\text { time }\end{array}$ & 4.2 \\
\hline 15 & $\begin{array}{l}\text { Companies respond quickly to complaints / } \\
\text { complaints from customers }\end{array}$ & 4.3 \\
\hline
\end{tabular}

risk level of ventilation quality remains excessive even after using two different protective layers. The bow tie model was adopted to determine the causes and consequences of ventilation quality. Preventive measures are used to improve the quality of sand casting with 16 safety measures. The results showed that the risk

that can occur in sand casting can be reduced by using bow tie analysis.

Susihono (2014) found that control measures that should be taken as part of risk management are to take immediate action in the form of substitution or improvement of work methods and become a priority for all work changes[3]. The company management must also conduct an evaluation and technical approach in the form of training and work direction to obtain a better working mechanism. Proposed improvement as an effort to reduce the hazard level identified in PT X Ceper metal casting, Klaten in the form 
The $1^{\text {st }}$ International Conference on Business and Engineering Management (IConBEM 2020)

February $1^{\text {st }} 2020$, Institut Teknologi Sepuluh Nopember, Surabaya, Indonesia

Table 5.

Reporting Risk Management Implementation

\begin{tabular}{|c|c|c|}
\hline No & Reporting Risk Implementation & Average \\
\hline 1 & $\begin{array}{l}\text { The company has a financial recording and } \\
\text { reporting system. }\end{array}$ & 4.1 \\
\hline 2 & $\begin{array}{l}\text { The company has an adequate internal control } \\
\text { system }\end{array}$ & 4 \\
\hline 3 & $\begin{array}{l}\text { The company will suffer financial losses if it } \\
\text { does not have adequate internal control. }\end{array}$ & 4.1 \\
\hline 4 & $\begin{array}{l}\text { The company is faced with actual losses if it is } \\
\text { unable to evaluate the company's internal } \\
\text { reports }\end{array}$ & 4 \\
\hline 5 & $\begin{array}{l}\text { The company effectively ensures that funds } \\
\text { will be used in the most beneficial way for the } \\
\text { company's future income and operations. }\end{array}$ & 3.1 \\
\hline 6 & $\begin{array}{l}\text { The company makes regular budget and } \\
\text { realization reports. }\end{array}$ & 4 \\
\hline 7 & $\begin{array}{l}\text { Incomplete and / or inaccurate information } \\
\text { (financial or non-financial) results in } \\
\text { inappropriate business decisions. }\end{array}$ & 4 \\
\hline 8 & $\begin{array}{l}\text { The current system is still vulnerable to } \\
\text { manipulation and that / transactions are not } \\
\text { adequately protected from accidental / } \\
\text { accidental manipulation or deletion. }\end{array}$ & 2.9 \\
\hline \multicolumn{3}{|c|}{$\begin{array}{c}\text { Table } 6 . \\
\text { Regulatory Risk Management Implementation }\end{array}$} \\
\hline No & Regulation Risk Implementation & Average \\
\hline 1 & $\begin{array}{l}\text { Changes in the law / regulation result in a } \\
\text { decrease in the ability of foundry } \\
\text { companies to conduct business efficiently. }\end{array}$ & 3.6 \\
\hline 2 & $\begin{array}{l}\text { Non-compliance with current laws and } \\
\text { regulations exposes the company to } \\
\text { sanctions, fines, penalties and threatens the } \\
\text { company's reputation }\end{array}$ & 3.4 \\
\hline 3 & $\begin{array}{l}\text { Company's non-compliance with tax } \\
\text { regulations can be avoided by good } \\
\text { evaluation }\end{array}$ & 3.8 \\
\hline
\end{tabular}

of improved mechanisms or work methods, especially at the printing station by paying attention to aspects of the type of work (task), organization and surrounding environment, as well as improving working environment conditions by modifying the suction device dust is portable, whereas heat caused by the effects of heat radiation on workers when carrying molten steel is to modify tools that are ergonomic and comfortable.

Damanik et al. (2016) conducted research on the identification of risk sources and risk assessment in the metal casting industry of PT. Bonjor Jaya in Ceper Klaten, by making SOPs for workers [1]. In the process of identifying and evaluating the risk of occupational accidents and the risk of occupational diseases in conventional metal casting rooms are: SOP design for workers who carry out the lifting of raw materials from trucks, filling raw materials into the kupola kitchen and the operation process of the kupola kitchen is labor those who are most at risk of occurrence of workplace accidents in the workplace, besides being exposed to chemicals which can interfere with the health of the workforce.

Mgonja (2017) found that the foundry and hazard industries, health effects and occupational safety measures in Tanzania and involving groups of affected workers. The results of his research also show that the casting industry contributes to environmental pollution and hazard in the casting industry is very diverse and dangerous for both the health of workers and the environment[4]. Kusumawardhani et al. (2017) examined the problems faced by the casting industry sector that cause hazards that lead to risks that affect health and work accidents [5]. An industry requires Occupational Health Safety (OHS) System with Hazard Identification Risk, Assessment and Risk Control (HIRARC) methods which, if implemented, will be able to easily find hazardous activities and can be immediately controlled according to high and low risk levels (urgent, high, medium and low). The results of this study indicate that the highest hazard categorized as urgent occurs in turning and welding rooms and production rooms included in the high category are the polish room, bromine room, grinding room, quality controlroom, product cleaning room or laundry room.

\section{II.RESEARCH METHOD}

The population was all metal casting companies that were members of the Batur Jaya Cooperative in Ceper Klaten, which totaled 155 . The sample selection method was convenience sampling, the number of questionnaires distributed was 80 , the returned questionnaires were 68 , so the response rate was 85 percent. The questionnaire regarding the implementation of risk management consists of four dimensions of risk, namely strategic risk, operating risk, reporting risk and regulatory risk, as measured by five Likert scales, namely Strongly Disagree, Disagree, Neutral, Agree and Strongly Agree.

\section{ANALYSIS AND DISCUSSION}

\section{A. Data Descriptive}

Following is respodent characteristics table 1.Based on the table 1 shows that the age of respondents at most $>40$ years is $50 \%$, while for between $31-40$ years it is $32.35 \%$ and between $20-30$ years it is $17.65 \%$. Male respondents were bigger at $75 \%$ while women were at $25 \%$. The distribution of respondents' positions is evenly distributed in accordance with the composition of positions, namely owners as much as $11.76 \%$, secretaries as much as $8.82 \%$, directors as much as $7.35 \%$, managers as much as.

\section{B. Analysis and Discussion}

Based on the results of data analysis regarding the implementation of risk management in metal casting companies using a questionnaire measured by five Likert scales of Strongly Disagree (1), Disagree (2), Neutral (3), Agree (4) and Strongly Agree (5) . Be aware of the respondent's answers then averaged. Following is the implementation of each dimension of risk management, presented in the following table 2 .

Based on the table 2, the implementation of strategic risk and operational risk has the highest average value, which is 3.8. This shows that the company has managed strategic risk and operational risk quite well. An average reporting risk of 3.7 means that the company is good enough in making records of finncial transactions and corporate financialreporting. While regulation risk shows the lowestaverage value compared to three other risk 
The $1^{\text {st }}$ International Conference on Business and Engineering Management (IConBEM 2020)

February $1^{\text {st }} 2020$, Institut Teknologi Sepuluh Nopember, Surabaya, Indonesia

dimensions, 3.6, it shows that the company has managed regulation risk adequately.

\section{Strategic Risk Management}

Implementation of strategic risk management is presented in the following table 3 . The company has anticipated changes that will have an impact on corporate strategy, such as price changes, new competitors, natural disasters, and technological changes. The company also understands that the existence of a company leader who has a good strategic planning, capable employees will improve company performance. The company has been quite focused on serving customer satisfaction, but the company has not been responsive enough in the face of changes in the market.

\section{D.Operational Risk Management}

Implementation of operational risk management is presented in the following table 4. Based on the table shows that the company has managed the production process adequately, employee health and safety is quite guaranteed, gives employees the right to improve the ability to improve performance through training, use of company assets and information in the organization quite efficiently. The company has managed a good relationship with suppliers and consumers. The interesting thing is that the company is relatively subjective in providing rewards and punishment in assessing employee performance. This can have an impact on decreased motivation for employees.

\section{E. Reporting Risk Management}

Implementation reporting risk management is presented in the following table 5. Based on the table shows that the company already has financial statement books to record financial transactions, has made reports and budget realization on a regular basis, has an adequate internal control system and conducts evacuation, even though the system is still vulnerable to manipulation and fraud and misuse of company funds.

\section{F. Regulatory Risk Management}

Implementation of regulatory risk management is presented in the following table 6 . Based on the table above shows that the company is quite obedient to the existing laws and regulations. The company has managed industrial waste adequately, providing protection and guarantee of employee rights in accordance with applicable regulations. An interesting result is that taxes are the regulations most companies adhere to to avoid legal sanctions.

\section{CONCLUSION AND LIMITATIONS}

Based on the results of the analysis it can be concluded that the metal casting company is good enough in managing strategic risk, operational risk and reporting. The company has also managed regulation risk adequately, even though its implementation is the lowest compared to other risk dimensions. The following are the implementation of the four dimensions of risk management carried out by metal casting companies members of the Batur Jaya Cooperative, Ceper, Klaten: a) strategic risk: the company has anticipated changes that will impact on the company's strategy, such as price changes, new competitors, natural disasters and technological change; b) operational Risk: the company has managed the production process adequately, the health and safety of employees is quite guaranteed, gives employees the right to improve their abilities through training, the use of company assets and information in the organization quite efficiently, and the company has managed a good relationship with suppliers and consumers. Reward and punishment has not been effective yet. The interesting thing is that the company is relatively subjective in providing rewards and punishment in assessing employee performance; c) reporting risk: the company already has a financial statement bookkeeping, has prepared a budget and realization report and has an adequate internal control system, although it is still vulnerable to manipulation and fraud; d) regulation risk: metal casting companies are sufficient in managing regulatory risk, especially in terms of compliance with tax regulations. This study only uses primary data to determine the implementation of risk management reporting,future research should use secondary data in the form of company financial statements.

\section{REFERENCES}

[1] L. H. Damanik, A. H. Husodo, and T. G. P. Hadi, "Analisis hazard identificationdan risk assessment di lingkungan kerja kegiatan pengecoran logam tradisional ceper klaten,” Nizham, vol. 05, no. 2, pp. 1-14, 2016.

[2] K.Vignesh and P.Dhiravidamani, "Designing sop for high pressure die casting by risk assessment technique,” Int. J. Sci. Eng. Technol. Res., vol. 4, no. 3, pp. 488-491, 2015.

[3] W. Susihono, "Hazard dan penilaian risiko pada industri pengecoran logam sistem tungku induksi (studi kasus di pt x ceper klaten),” in Seminar Nasional IDEC, 2014, pp. 274-283.

[4] C. T. Mgonja, "A review on effects of hazards in foundries to workers and environment,” IJISET-International J. Innov. Sci. Eng. Technol., vol. 4, no. 6, pp. 326-334, 2017, doi: 10.13140/RG.2.2.24642.27847.

[5] D. Kusumawardhani, H. S. Kasjono, and P. Purwanto, “Analisis hazard identification risk assessment, and risk control (hirarc) di bagian finishing 2 industri serikat pekerja aluminium sorosutan tahun 2017,” Sanitasi J. Kesehat. Lingkung., vol. 9, no. 1, p. 1, 2017, doi: 10.29238/sanitasi.v9i1.40. 